\title{
Uusi palvelu Taloustohtorissa - kasvihuonekaasupäästöjen laskenta
}

Kristiina Regina ${ }^{1)}$, Arto Latukka ${ }^{2}$, Aleksi Lehtonen ${ }^{3)}$, Sanna Pitkänen ${ }^{1)}$, Mika Sulkava ${ }^{2)}$, Olli Salminen ${ }^{3)}$ ${ }^{1)}$ Luke, Biotalous ja ympäristö, Tietotie 4, 31600 Jokioinen, kristiina.regina(at)luke.fi, sanna.pitkanen(at)luke.fi

${ }^{2}$ Luke, Tilastopalvelut, PL 2, 00791 Helsinki, arto.latukka(at)luke.fi, mika.sulkava(at)luke.fi

${ }^{3)}$ Luke, Biotalous ja ympäristö, PL 2, 00791 Helsinki, aleksi.lehtonen(at)luke.fi, olli.salminen(at)luke.fi

Maatalouden tuottamat kasvihuonekaasupäästöt raportoidaan YK:n Ilmastosopimuksen ja Kioton pöytäkirjan mukaisesti osana Suomen kokonaispäästöjä. Hallitustenvälisen ilmastonmuutospaneelin (IPCC) ohjeiden mukainen päästölaskenta on rakennettu niin, että maankäyttöä, maataloutta ja tilojen energiankäyttöä tarkastellaan erillään toisistaan. Yhteensä kaikki maatalousperäiset päästöt ovat noin 20\% Suomen kokonaispäästöistä. Raportointisektorit ylittävä tarkastelu mahdollistaa maatilan tarkastelun kokonaisuutena.

Luonnonvarakeskuksen (Luke) Taloustohtori-verkkopalvelu (www.luke.fi/taloustohtori) tarjoaa suuren määrän kannattavuuskirjanpitotilojen tietojen pohjalta laskettuja maa- ja puutarhatalousyritysten tulostietoja. Taloustohtori-järjestelmään rakennettiin verkkopalvelu, joka antaa kannattavuuskirjanpitotiloille mahdollisuuden tarkastella oman tilan kasvihuonekaasulaskelmia ja verrata tuloksia eri tilaryhmien keskiarvotuloksiin. Kuka tahansa pääsee tarkastelemaan tietojen pohjalta yleistettyjä keskiarvotietoja. Uusi verkkopalvelu sisältää maataloussektorin päästöt, turvepeltojen hiilidioksidipäästöt maankäytöstä ja tuotantoon liittyvän energiankäytön päästöt.

Uudessa palvelussa kannattavuuskirjanpitotiloille lasketaan kasvihuonekaasupäästöt taannehtivasti vuodesta 2000 lähtien. Kannattavuuskirjanpidon raportointijärjestelmillä nämä tulokset painotetaan yleistettäväksi alueellisiksi keskiarvo- ja kokonaistuloksiksi, joten verkkopalvelu tarjoaa tietoa kaikille maatiloille ja myös maatalouspoliittiselle päätöksenteolle. Myös päästövähennysten taloudellisten vaikutusten tarkastelua voidaan kehittää, koska kannattavuuskirjanpitoaineisto sisältää sekä taloustiedot että tuotantotiedot.

Kasvihuonekaasupäästöt lasketaan reaaliaikaisesti havainto- ja yrityskohtaisesta aineistosta. Suurin osa laskennassa tarvittavista tiedoista on Taloustohtorin tietokannassa. Kasvihuonekaasujen laskenta noudattaa IPCC:n 2006 Guidelines -ohjeistoa ja on yhdenmukainen Suomen kasvihuonekaasuinventaariossa käytettävien menetelmien kanssa. Kasvihuonekaasuinventaariossa käytettyjä menetelmiä yksinkertaistettiin hieman esimerkiksi käyttämällä keskiarvotietoja tietystä päästölähteestä perustuen raportoituihin päästöihin, jotta järjestelmän ylläpitotyömäärä pysyy kohtuullisena. Näin myöskään laskennassa tarvittava tietomäärä ei nouse kohtuuttoman suureksi.

Laskennan lopputuloksena raportoidaan sekä tilakohtaisesti että alueellisesti 1. metaanipäästöt tuotantoeläimistä ja lannasta, 2. dityppioksidipäästöt lannasta ja maaperästä, 3. hiilidioksidipäästöt kalkituksesta, 4. hiilidioksidipäästöt eloperäisten peltojen maaperästä. 5. hiilidioksidipäästöt maatilan energiankäytöstä.

Asiasanat: kasvihuonekaasu, hiilidioksidi, metaani, dityppioksidi, maatalous, kannattavuuskirjanpito, taloustohtori 


\section{Johdanto}

Maatalouden tuottamat kasvihuonekaasupäästöt raportoidaan YK:n Ilmastosopimuksen ja Kioton pöytäkirjan mukaisesti osana Suomen kokonaispäästöjä. Yhteensä kaikki maatalousperäiset päästöt ovat noin 20\% Suomen kokonaispäästöistä. Hallitustenvälisen ilmastonmuutospaneelin (IPCC) ohjeiden mukainen päästölaskenta on rakennettu niin, että maankäyttöä, maataloutta ja tilojen energiankäyttöä tarkastellaan erillään toisistaan. Raportointisektorit ylittävä tarkastelu mahdollistaa maatilan tarkastelun kokonaisuutena.

Maatalouden kasvihuonekaasupäästöinä raportoidaan metaanipäästöjä $\left(\mathrm{CH}_{4}\right)$ tuotantoeläinten ruuansulatuksesta tai lannasta, dityppioksidipäästöjä $\left(\mathrm{N}_{2} \mathrm{O}\right)$ lannankäsittelystä tai maaperästä ja hiilidioksidipäästöjä $\left(\mathrm{CO}_{2}\right)$ kalkituksesta ja urean käytöstä. Lisäksi osana maankäytön päästöjä raportoidaan maaperän hiilidioksidi- ja dityppioksidipäästöjä. Maatalouden energiankäytön päästöt syntyvät pääasiassa työkoneista, rakennusten lämmityksestä ja viljankuivauksesta.

Tilan omistaja on paras asiantuntija valitsemaan toteuttamiskelpoiset päästövähennystoimet omalla tilallaan. Tähän mennessä ei kuitenkaan ole ollut mahdollista arvioida tilannetta ja tehtyjen toimien vaikuttavuutta tilakohtaisesti. Tässä artikkelissa esitellään maatilakohtainen kasvihuonekaasupäästöjen laskentajärjestelmä, joka rakennettiin osaksi Luonnonvarakeskuksen (Luke) Taloustohtoriverkkopalvelua. Järjestelmän avulla on mahdollista laskea kasvihuonekaasupäästöt Taloustohtorin laskennan pohjana oleville kannattavuuskirjanpitotiloille ja yleistää siitä keskiarvotietoja esimerkiksi alueen, tuotantosuunnan tai tilakoon mukaan luokiteltuna.

Palvelun tarkoituksena on havainnollistaa käyttäjille mistä päästöt tulevat ja mitkä ovat päästölähteistä olennaisimpia. Kirjanpitotilalliset voivat nähdä aikasarjasta tilan käytäntöjen muuttumisen vaikutukset päästöjen tasoon ja jakautumiseen eri päästölähteiden kesken. Keskiarvotuloksia voivat käyttää esimerkiksi alueellisten ilmastostrategioiden tai maatalouden tukipolitiikan suunnittelijat.

\section{Aineisto ja menetelmät}

\section{Kannattavuuskirjanpitoaineisto ja muut aineistot}

Suomen maa- ja puutarhatalousyritysten kannattavuutta kuvaavat luvut lasketaan vuosittain Luken kannattavuuskirjanpidon perusteella. Nämä kannattavuusluvut kuvaavat noin 50000 yrityksen keskimääräisiä tuloksia. Tilojen kannattavuutta tarkkaillaan noin 900 tilan otoksen avulla. Tässä työssä käytetään vuosien 2000-2015 aineistoa. Kannattavuuskirjanpidon alkuperäisenä tavoitteena on ollut edustaa 40000 Suomen suurinta tilaa, ja tämän vuoksi otoksessa on melko vähän pieniä tiloja. Alueellisten kasvihuonekaasupäästöjen laskennan kannalta tällä ei ole suurta merkitystä pienten tilojen tyypillisesti pienten päästöjen sekä otospainojen kalibroinnin (Sulkava ym. 2015) takia.

Kannattavuuskirjanpitoaineistoon kerätään tiloilta tuhansia muuttujia. Tässä työssä tarvittavista muuttujista suurin osa on olemassa kirjanpitoaineistossa jo valmiiksi. Keskeisiä laskennassa tarvittavia muuttujia ovat tilan eläinten lukumäärät, viljelykasvien tuotantomäärät, turvemaiden ja kivennäismaiden pinta-alat sekä koneiden käyttämiseen ja rakennusten lämmittämiseen käytettyjen polttoaineiden määrät. Polttoaineiden määristä ei ole kaikilta tiloilta saatavissa tietoa suoraan, vaan määrät joudutaan laskemaan tilan polttoainekustannuksista käyttäen polttoaineiden keskimääräisiä hintoja. Latukka (1998) ja Community Committee for the Farm Accountancy Data Network (2009) tarjoavat tarkempaa tietoa kannattavuuskirjanpidon muuttujista.

Tiloilla käytössä oleva lannankäsittelyjärjestelmä vaikuttaa päästöihin, mutta lannankäsittelyjärjestelmistä on kirjanpitoaineistossa vain epävarmaa tietoa. Tämän vuoksi tämä tieto tullaan jatkossa keräämään kirjanpitotiloilta suuremmalla tarkkuudella. Tietoa väkilannoitteiden käyttömääristä tiloilla aletaan kerätä vuodesta 2016 lähtien, ja aiemmille vuosille se arvioidaan lannoituskustannuksen mukaan. Tilakohtainen käytetyn kalkin määrä saadaan laskettua kustannusten perusteella. Eloperäisten peltojen pinta-alana käytetään tällä hetkellä kunnan keskimääräistä osuutta, koska peltolohkokohtaista tietoa ei vielä ole palvelun käytössä.

\section{Taloustohtori}

Luken Taloustohtori-verkkopalvelu (www.luke.fi/taloustohtori) tarjoaa suuren määrän kannattavuuskirjanpitotilojen tietojen pohjalta laskettuja maa- ja puutarhatalousyritysten tulostietoja. Taloustohtorissa on myös runsaasti muunkinlaista alkutuotantoon, kuten rannikkokalastukseen sekä poro- ja mehiläistalouteen liittyvää tietoa. Taloustohtori-järjestelmään rakennettiin vuosien 2015-2016 aikana 
verkkopalvelu, joka antaa kannattavuuskirjanpitotiloille mahdollisuuden tarkastella oman tilan kasvihuonekaasulaskelmia ja verrata tuloksia eri tilaryhmien keskiarvotuloksiin. Taloustohtorin kasvihuonekaasupäästöjen laskentapalvelun keskeneräistä kehitysversiota on esitelty jo edellisillä Maataloustieteen päivillä (Sulkava ym. 2016).

\section{Kasvihuonekaasupäästöjen laskenta}

Kannattavuuskirjanpitotiloille lasketaan maatalouden kasvihuonekaasulaskentatulokset taannehtivasti vuodesta 2000 lähtien. Kannattavuuskirjanpidon raportointijärjestelmillä nämä tulokset painotetaan yleistettäväksi alueellisiksi keskiarvo- ja kokonaistuloksiksi, joten verkkopalvelu tarjoaa tietoa kaikille maatiloille ja myös maatalouspoliittiselle päätöksenteolle. Myös päästövähennysten taloudellisten vaikutusten tarkastelua voidaan kehittää, koska kannattavuuskirjanpitoaineisto sisältää sekä taloustiedot että tuotantotiedot. Laskennan lopputuloksena raportoidaan sekä tilakohtaisesti että alueellisesti taulukossa 1 esitetyt päästölajit. Valittavissa olevia luokitteluvaihtoehtoja ovat vuosi, tukialue, ProAgriakeskus, tuotantosuunta ja taloudellinen koko.

Kasvihuonekaasupäästöjen laskenta tapahtuu SAS-ohjelmistossa ja suurin osa laskennassa tarvittavista tiedoista on Taloustohtorin tietokannassa. Kasvihuonekaasujen laskenta noudattaa IPCC:n 2006 Guidelines -ohjeistoa (IPCC 2006), ja laskenta on yhdenmukainen Suomen kasvihuonekaasuinventaariossa käytettävien menetelmien kanssa. Kasvihuonekaasuinventaariossa käytettyjä menetelmiä yksinkertaistetaan hieman esimerkiksi käyttämällä keskiarvotietoja tietystä päästölähteestä perustuen raportoituihin päästöihin, jotta järjestelmän ylläpitotyömäärä pysyy kohtuullisena.

\section{Tulokset ja tulosten tarkastelu}

Palvelu on helppokäyttöinen ja raportit selkeitä tulkita. Kuvien esimerkit antavat viitteitä siitä, mihin palvelusta saatavia tietoja voidaan käyttää. Päästöjä voidaan tarkastella sekä tilaa tai aluetta kohden että taloudellista tuotosta kohden. Tilakoko ei määritä viljatilojen päästöjä tuotosta kohden, vaikka tilakokoluokkien välillä onkin jonkin verran vaihtelua (Kuva 1). Vaihtelu näyttäisi syntyvän tässä tarkastelussa enimmäkseen eloperäisten peltojen yleisyyden mukaan.

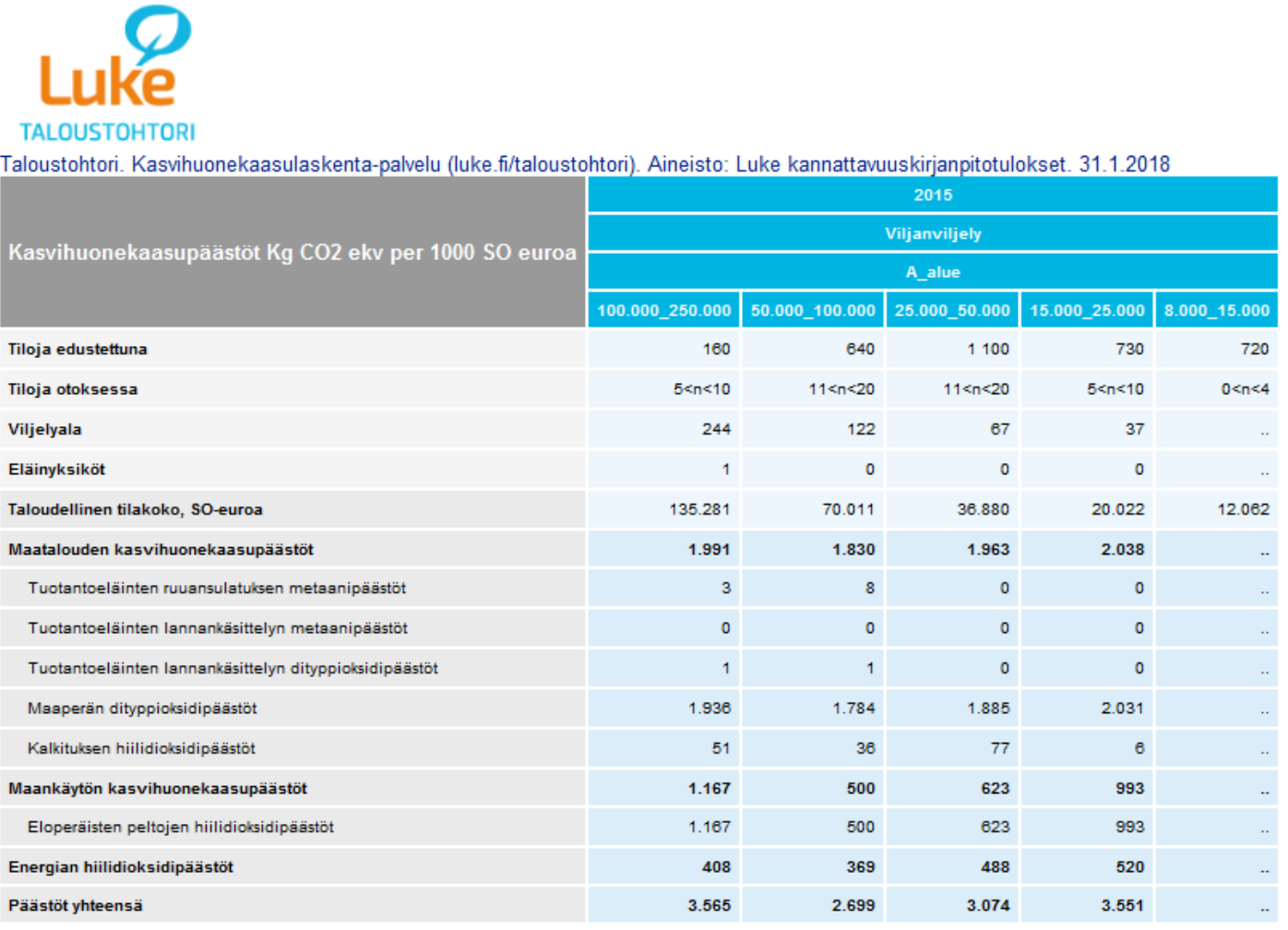

Palvelun tuottaa: Luonnonvarakeskus, Luke | www.luke.fi

Kuva 1. Esimerkki Taloustohtorin kasvihuonekaasulaskenta -palvelun tuloksista: Viljatilojen päästöt A-tukialueella tilakokoluokittain tuotettua 1000 euroa kohden

Sekä maitotilat että lypsylehmät ovat kasvaneet kooltaan tarkastelujaksolla, ja se näkyy kohonneina 
päästöinä tilaa kohden (tuloksia ei esitetty). Positiivista kuitenkin on se, että tuotettua 1000 euroa kohden päästöt ovat ennemminkin laskeneet (Kuva 2). Siitä voi päätellä, että tuotos on kasvanut enemmän kuin eläinkohtaiset päästöt.

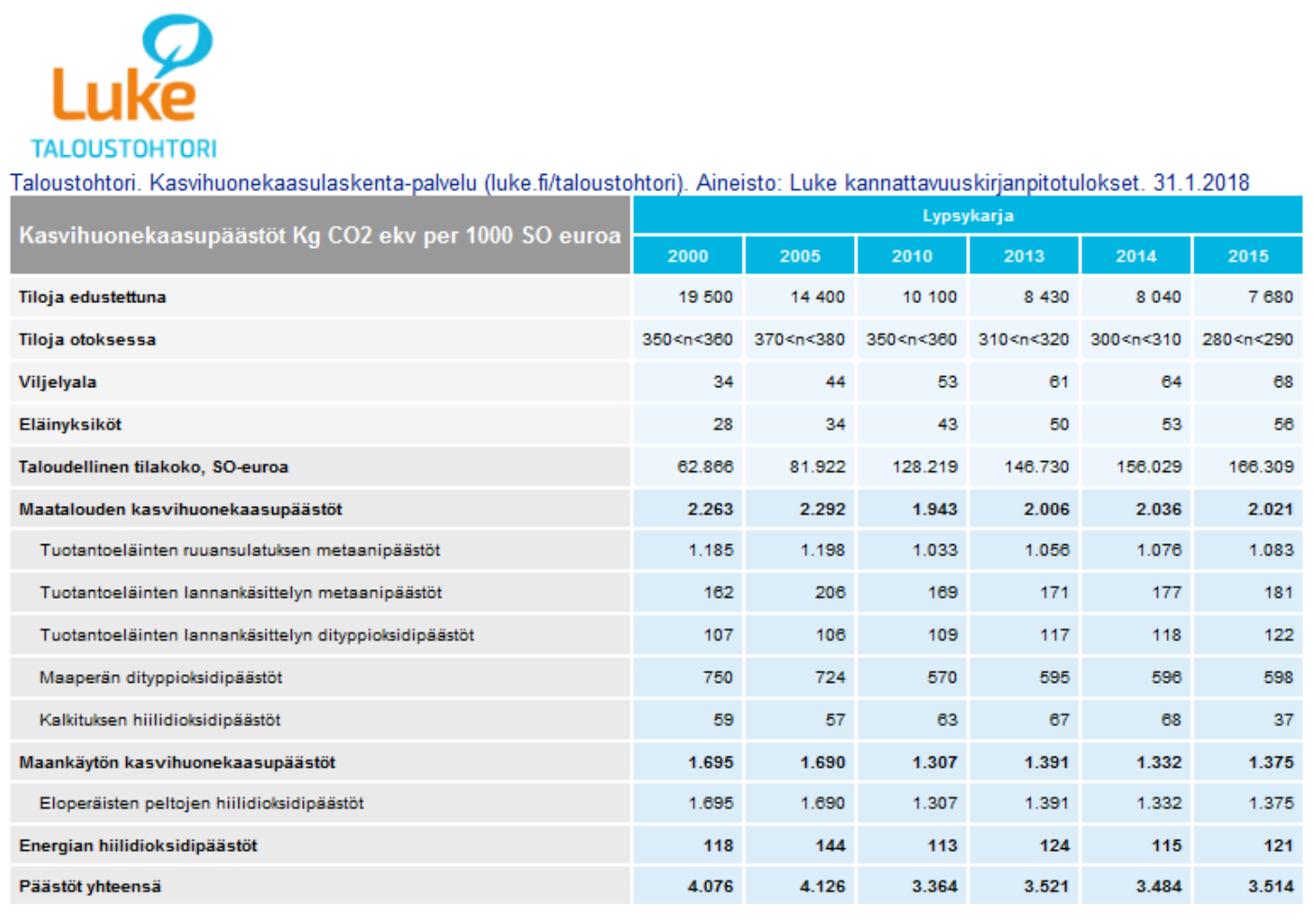

Palvelun tuottaa: Luonnonvarakeskus, Luke | www.luke.fi

Kuva 2. Esimerkki Taloustohtorin kasvihuonekaasulaskenta -palvelun tuloksista: Maitotilojen päästöt tuotettua 1000 euroa kohden

Alueellisesti voidaan tarkastella esimerkiksi eri tuotantosuuntien tai maalajien jakautumisen vaikutuksia alueen kasvihuonekaasupäästöihin. Tulokset osoittivat, että eloperäisten peltojen päästöt tuotettua 1000 euroa kohden ovat viljanviljelyssä C2-tukialueella seitsenkertaiset verrattuna A-tukialueeseen (tuloksia ei esitetty). Tämä johtuu siitä, että eloperäisten peltojen osuus kasvaa pohjoiseen päin.

Palveluun on tarkoitus vielä lisätä metsien ja kivennäismaiden peltojen hiilivarastojen tarkastelu sekä olennaisimpien maankäytön muutosten kuten pellonraivauksen päästöt. Eloperäisten peltojen alan kohdentaminen pystytään tekemään paremmin jatkokehityksessä. Kehitteillä on myös simulointimahdollisuus, joka auttaisi tilanomistajia valitsemaan päästövähennystoimia.

\section{Johtopäätökset}

Uuden palvelun avulla voidaan tarkastella esimerkiksi maatalouspolitiikan ja maatalouden rakennekehityksen vaikutuksia kasvihuonekaasujen päästöihin. Vaikka laskentaa on jouduttu yksinkertaistamaan ja tuloksissa on siten enemmän epävarmuutta kuin virallisessa päästötilastoinnissa, kehityskulut aikasarjassa kertovat todellisista muutoksista. Kasvihuonekaasulaskennan liittäminen Taloustohtorin palveluksi tuo uuden mahdollisuuden viestiä maatalouden ilmastovaikutuksista ja päästövähennysmahdollisuuksista maataloudessa.

\section{Kirjallisuus}

Community Committee for the Farm Accountancy Data Network 2009. Typology handbook, Tech. Rep. RI/CC 1500 rev. 3, European Commission - Directorate-General for Agriculture and Rural Development. 
IPCC 2006. 2006 IPCC Guidelines for National Greenhouse Gas Inventories. Prepared by the National Greenhouse Gas Inventories Programme. Eggleston H.S., Buendia L., Miwa K., Ngara T. \& Tanabe K. (toim.). Japan, Institute for Global Environmental Strategies.

Latukka, A. 1998. Maatalousyritysten tulorahoituksen riittävyyden ennustaminen neuroverkkomenetelmällä, lisensiaatintutkimus, Helsingin yliopisto, Taloustieteen laitos, Julkaisuja nro 22, Maatalouden liiketaloustiede.

Sulkava, M., Latukka, A., Lehtonen, A., Pitkänen, S., Regina, K. \& Salminen, O. 2016. Tilakohtainen kasvihuonekaasupäästöjen laskenta Taloustohtorissa. Teoksessa: Schulman, N. \& Helin, J. (toim.), Maataloustieteen päivät 2016. Suomen Maataloustieteellisen Seuran julkaisuja 33.

Sulkava, M., Sepponen, A.-M., Yli-Heikkilä, M. \& Latukka, A. 2015. Clustering of the self-organizing map reveals profiles of farm profitability and upscaling weights. Neurocomputing 147:197-206. 